\title{
GENETIC DIVERGENCE BETWEEN PUMPKIN ACCESSIONS FOR MORPHOAGRONOMIC CHARACTERS
}

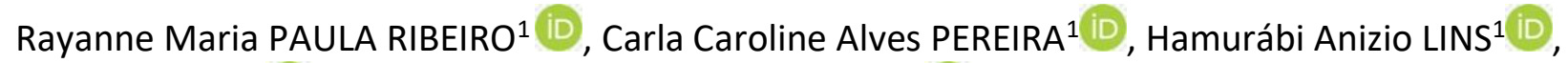
Michele BARBOZA ${ }^{1}$ (D), Islan Diego Espindula de CARVALHO ${ }^{2}$ iD, Glauber Henrique de Sousa NUNES ${ }^{3}$, Lindomar Maria da SILVEIRA ${ }^{3}$ iD , Aurélio Paes BARROS JÚNIOR ${ }^{3}$ iD

${ }^{1}$ Postgraduate Program in Phytotechnics, Universidade Federal Rural do Semi-Árido, Mossoró, Rio Grande do Norte, Brazil.

2 Postgraduate Program in Plant Genetic Improvement, Universidade Federal Rural de Pernambuco, Recife, Pernambuco, Brazil.

${ }^{3}$ Department of Agronomic and Forestry Sciences, Universidade Federal Rural do Semi-Árido, Mossoró, Rio Grande do Norte, Brazil.

Corresponding author:

Hamurábi Anizio Lins

Email: hamurabi.lins@alunos.ufersa.edu.br

How to cite: PAULA RIBEIRO, R.M., et al. Genetic divergence between pumpkin accessions for morphoagronomic characters. Bioscience Journal. 2022, 38, e38002. https://doi.org/10.14393/BJ-v38n0a2022-54198

\section{Abstract}

The objective of this work was to evaluate the diversity between accessions of Cucurbita moschata from the Northeast of Brazil and preserved at the Universidade Federal Rural do Semi-Árido (UFERSA) in Mossoró-RN. The experiment was carried out in complete randomized blocks, with two replications and three plants per plot. The treatments consisted of 51 accessions of $C$. moschata Duch and a commercial cultivar of Cucurbita maximum Duch. After ripening, the fruits were harvested (one fruit per plant) and evaluated for morphoagronomic descriptors. Univariate and multivariate variance analyzes were performed. From the dissimilarity matrices, accessions were hierarchically grouped by the UPGMA method. The relative contribution of quantitative characters to the divergence was also estimated. There was an effect of accessions $(p<0.01$ or $p<0.05)$ for all characters in univariate analyzes, indicating that there is heterogeneity between the accessions evaluated. Considering the quantitative descriptors, the accessions formed eight groups and for the qualitative six groups. When considering the two sets of descriptors, the accessions were distributed in eight groups but presenting a greater distribution of accessions. The descriptors that most contributed to the discrimination of accessions were the firmness of the pulp and the length of the fruit.

Keywords: Cucurbita moschata Duch. Diversity. Grouping.

\section{Introduction}

Pumpkin (Cucurbita moschata Duch) is a species traditionally used in the food of the Brazilian population, as it has great versatility in food preparation, such as pumpkin in syrup, jams, purees, pies, soups, stews, and breads. In addition to the pulp, the seeds and flowers of the pumpkin have also been consumed and used in recipes (Gliemmo et al. 2009; Guiné et al. 2012). Pumpkin is an easily produced crop, versatile in cultivation, with great genetic variability in relation to adaptation to environmental conditions, growth habits, and resistance to diseases (Veronezi and Jorge 2012).

In Brazil, commercial pumpkin crops use hybrid seeds. In small rural properties, accessions adapted to the region of cultivation, from open pollination, are used (Santos et al. 2015). In the Northeast Region of Brazil, the cultivation of pumpkin accessions is the most widespread, and the fruits have strong acceptance in the market, using seeds selected by the farmers themselves. 
In breeding studies, the characterization and evaluation steps allow identifying the genetic variability of accessions, contributing to the selection of promising genotypes, and the establishment of conservation strategies and future breeding actions (Borges et al. 2011).

The characterization, whether morphological, cytological, biochemical, physiological, or molecular, can be performed through qualitative and quantitative descriptors (Costa et al. 2009; Paula Ribeiro et al. 2020), being an important tool in the study of plant genetic resources. This phase of the study, which consists of measuring data to describe, identify and differentiate accessions of the same species, provides useful information for the conservation of germplasm collections and banks and the choice of superior genotypes (Burle and Oliveira 2010).

On the other hand, it is important to note that depending on the type of descriptors used for the characterization, it is possible to identify accessions that can be indicated for direct use by farmers. Considering the economic and social context in which the pumpkin culture is inserted, such a result can result in saving time and resources for breeders, as well as adding value to production.

Therefore, the objective of the work was to evaluate the divergence levels between pumpkin accessions in Northeast Brazil and preserved at the Federal Rural University of Semi-Arid (UFERSA) in Mossoró-RN.

\section{Material and Methods}

\section{Place}

The experiment was carried out at the UFERSA Experimental Farm, Mossoró-RN $\left(5^{\circ} 11^{\prime}\right.$ latitude $\mathrm{S}, 37^{\circ}$ 20' longitude W Greenwich, altitude $18 \mathrm{~m}$ ), from September 2017 to February 2018.

The average temperature in the region is $27.2{ }^{\circ} \mathrm{C}$ and annual precipitation of $766 \mathrm{~mm}$ (Alvares et al. 2013; Borges et al. 2015). The soil of the experimental area is characterized as Typical Red Dystrophic Argisol (Rêgo et al. 2016). Climatic data were collected during the period of the experiments and are shown in Figure 1.
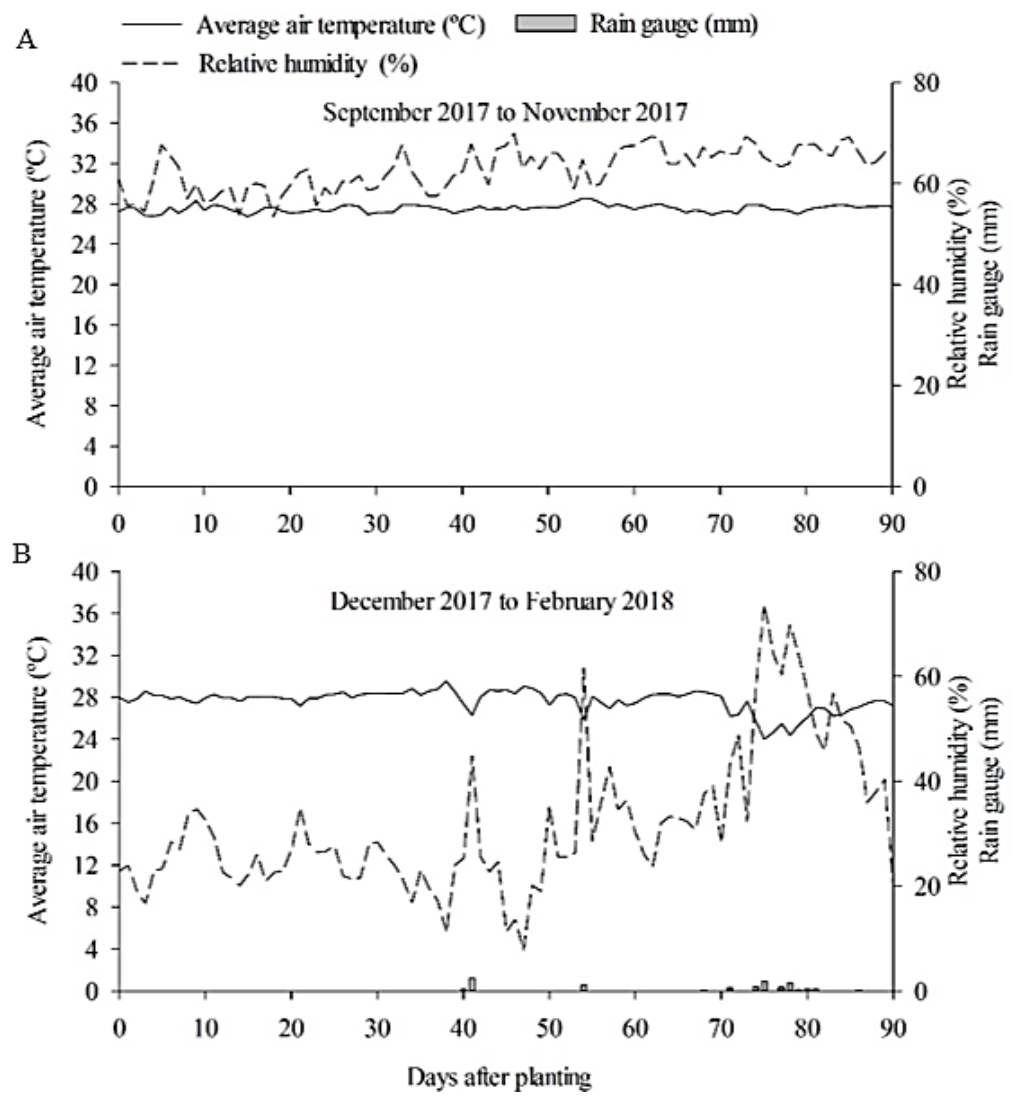

Figure 1. A - average air temperature $(\stackrel{\circ}{ } \mathrm{C})$, relative humidity $(\%)$ and rainfall $(\mathrm{mm})$ referring to experiment $1 ; B$ - average air temperature $(\stackrel{\circ}{ } \mathrm{C})$, relative humidity $(\%)$ and rainfall $(\mathrm{mm})$ referring to the experiment 2 .

Source: INMET Automatic Meteorological Station, and rain gauge from Experimental Farm Rafael Fernandes. 


\section{Germplasm}

51 accessions of $C$. moschata Duch belonging to the UFERSA Cucurbitaceae germplasm collection and a commercial cultivar of $C$. maxima Duch (Moranga Coroa, ISLA ${ }^{\circledR}$ ) were evaluated (Table 1 ). The species $C$. maxima Duch was used as an extra object in the study of genetic divergence within the species $C$. moschata Duch. This practice is common in studies of diversity with close species.

Table 1. Accessions of Cucurbita sp1 belonging to the UFERSA Cucurbitaceae germplasm collection.

\begin{tabular}{|c|c|c|c|c|}
\hline Treatments & Code $^{2}$ & Origin $^{3}$ & Location & Collection date \\
\hline $\mathrm{T} 1$ & ABO01 & Rio do Fogo-RN & 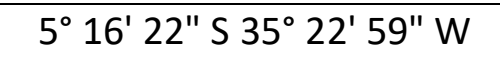 & $16 / 09 / 2010$ \\
\hline $\mathrm{T} 2$ & ABO02 & Touros-RN & 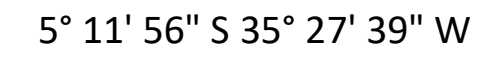 & $20 / 12 / 2010$ \\
\hline T3 & ABO03 & Touros-RN & $5^{\circ} 11^{\prime} 56^{\prime \prime} \mathrm{S} 35^{\circ} 27^{\prime} 39^{\prime \prime} \mathrm{W}$ & $20 / 12 / 2010$ \\
\hline T4 & ABO04 & Macaíba-RN & $05^{\circ} 56^{\prime} 31^{\prime \prime} \mathrm{S} 35^{\circ} 22^{\prime} 04^{\prime \prime} \mathrm{W}$ & $15 / 05 / 2014$ \\
\hline T5 & ABO05 & Rio do Fogo-RN & $5^{\circ} 16^{\prime} 22^{\prime \prime} \mathrm{S} 35^{\circ} 22^{\prime} 59^{\prime \prime} \mathrm{W}$ & $16 / 09 / 2010$ \\
\hline T6 & ABO06 & Rio do Fogo-RN & $5^{\circ} 16^{\prime} 22^{\prime \prime} \mathrm{S} 35^{\circ} 22^{\prime} 59^{\prime \prime} \mathrm{W}$ & $16 / 09 / 2010$ \\
\hline $\mathrm{T7}$ & ABO07 & Touros-RN & $5^{\circ} 11^{\prime} 56^{\prime \prime} \mathrm{S} 35^{\circ} 27^{\prime} 39^{\prime \prime} \mathrm{W}$ & $20 / 12 / 2010$ \\
\hline T8 & ABO08 & Rio do Fogo-RN & $5^{\circ} 16^{\prime} 22^{\prime \prime} \mathrm{S} 35^{\circ} 22^{\prime} 59^{\prime \prime} \mathrm{W}$ & $16 / 09 / 2010$ \\
\hline T9 & ABO09 & Touros-RN & $5^{\circ} 11^{\prime} 56^{\prime \prime} \mathrm{S} 35^{\circ} 27^{\prime} 39^{\prime \prime} \mathrm{W}$ & $20 / 12 / 2010$ \\
\hline T10 & ABO10 & Touros-RN & $5^{\circ} 11^{\prime} 56^{\prime \prime} \mathrm{S} 35^{\circ} 27^{\prime} 39^{\prime \prime} \mathrm{W}$ & $20 / 12 / 2010$ \\
\hline T11 & AB011 & -4 & - & - \\
\hline T12 & ABO12 & Currais Novos-RN & $6^{\circ} 15^{\prime} 39^{\prime \prime} \mathrm{S} 36^{\circ} 31^{\prime} 04^{\prime \prime} \mathrm{W}$ & $28 / 10 / 2010$ \\
\hline T13 & ABO13 & Currais Novos-RN & $6^{\circ} 15^{\prime} 39^{\prime \prime} \mathrm{S} 36^{\circ} 31^{\prime} 04^{\prime \prime} \mathrm{W}$ & $28 / 10 / 2010$ \\
\hline T14 & ABO14 & Currais Novos-RN & $6^{\circ} 15^{\prime} 39^{\prime \prime} \mathrm{S} 36^{\circ} 31^{\prime} 04^{\prime \prime} \mathrm{W}$ & $28 / 10 / 2010$ \\
\hline T15 & ABO15 & Ceará Mirim-RN & $5^{\circ} 12^{\prime} 12^{\prime \prime} \mathrm{S} 37^{\circ} 19^{\prime} 30^{\prime \prime} \mathrm{W}$ & $13 / 05 / 2014$ \\
\hline T16 & AB016 & Touros-RN & $5^{\circ} 11^{\prime} 56^{\prime \prime} \mathrm{S} 35^{\circ} 27^{\prime} 39^{\prime \prime} \mathrm{W}$ & $20 / 12 / 2010$ \\
\hline T17 & ABO17 & Rio do Fogo-RN & $5^{\circ} 16^{\prime} 22^{\prime \prime} \mathrm{S} 35^{\circ} 22^{\prime} 59^{\prime \prime} \mathrm{W}$ & $16 / 09 / 2010$ \\
\hline T18 & AB018 & Rio do Fogo-RN & 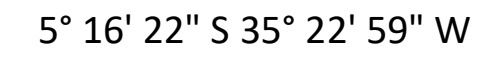 & $16 / 09 / 2010$ \\
\hline T19 & AB019 & Rio do Fogo-RN & 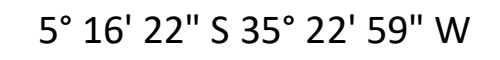 & $16 / 09 / 2010$ \\
\hline T20 & $\mathrm{ABO} 20$ & Touros-RN & $5^{\circ} 11^{\prime} 56^{\prime \prime} \mathrm{S} 35^{\circ} 27^{\prime} 39^{\prime \prime} \mathrm{W}$ & $20 / 12 / 2010$ \\
\hline $\mathrm{T} 21$ & $\mathrm{ABO} 21$ & Rio do Fogo-RN & $5^{\circ} 16^{\prime} 22^{\prime \prime} \mathrm{S} 35^{\circ} 22^{\prime} 59^{\prime \prime} \mathrm{W}$ & $21 / 12 / 2010$ \\
\hline $\mathrm{T} 22$ & $\mathrm{ABO} 22$ & Rio do Fogo-RN & 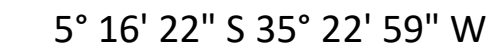 & $16 / 09 / 2010$ \\
\hline T23 & $\mathrm{ABO} 23$ & Rio do Fogo-RN & $5^{\circ} 16^{\prime} 22^{\prime \prime} \mathrm{S} 35^{\circ} 22^{\prime} 59^{\prime \prime} \mathrm{W}$ & $16 / 09 / 2010$ \\
\hline T24 & $\mathrm{ABO} 24$ & Rio do Fogo-RN & $5^{\circ} 16^{\prime} 22^{\prime \prime} \mathrm{S} 35^{\circ} 22^{\prime} 59^{\prime \prime} \mathrm{W}$ & $16 / 09 / 2010$ \\
\hline $\mathrm{T} 25$ & $\mathrm{ABO} 25$ & João Câmara-RN & 5o 32' 17" S 35 48' 39" W & $14 / 05 / 2014$ \\
\hline T26 & ABO26 & Rio do Fogo-RN & 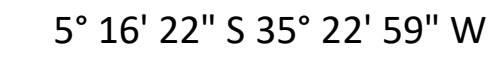 & $16 / 09 / 2010$ \\
\hline T27 & $\mathrm{ABO} 27$ & - & - & - \\
\hline T28 & ABO28 & Touros-RN & $5^{\circ} 11^{\prime} 56^{\prime \prime} \mathrm{S} 35^{\circ} 27^{\prime} 39^{\prime \prime} \mathrm{W}$ & $20 / 12 / 2010$ \\
\hline T29 & ABO29 & Assú-RN & $5^{\circ} 34^{\prime} 56^{\prime \prime} \mathrm{S} 36^{\circ} 56^{\prime} 40^{\prime \prime} \mathrm{W}$ & $22 / 03 / 2017$ \\
\hline T30 & ABO30 & Assú-RN & $5^{\circ} 34^{\prime} 56^{\prime \prime} \mathrm{S} 36^{\circ} 56^{\prime} 40^{\prime \prime} \mathrm{W}$ & $22 / 03 / 2017$ \\
\hline T31 & ABO31 & Assú-RN & $5^{\circ} 34^{\prime} 56^{\prime \prime} \mathrm{S} 36^{\circ} 56^{\prime} 40^{\prime \prime} \mathrm{W}$ & $22 / 03 / 2017$ \\
\hline T32 & ABO33 & Rio do Fogo-RN & $5^{\circ} 16^{\prime} 22^{\prime \prime} \mathrm{S} 35^{\circ} 22^{\prime} 59^{\prime \prime} \mathrm{W}$ & $16 / 09 / 2010$ \\
\hline T33 & $\mathrm{ABO} 34$ & Ipanguaçu-RN & $5^{\circ} 28^{\prime} 31^{\prime \prime} \mathrm{S} 36^{\circ} 51^{\prime} 58^{\prime \prime} \mathrm{W}$ & $22 / 06 / 2017$ \\
\hline T34 & ABO35 & - & - & - \\
\hline T35 & AB036 & - & - & - \\
\hline T36 & ABO37 & Mossoró-RN & $5^{\circ} 12^{\prime} 12^{\prime \prime} \mathrm{S} 37^{\circ} 21^{\prime} 08^{\prime \prime} \mathrm{W}$ & 21/08/1999 \\
\hline T37 & $\mathrm{ABO} 38$ & - & - & - \\
\hline T38 & ABO39 & - & - & - \\
\hline T39 & ABO40 & - & - & - \\
\hline T40 & $\mathrm{ABO} 41$ & Ipanguaçu-RN & $5^{\circ} 28^{\prime} 31^{\prime \prime} \mathrm{S} 36^{\circ} 51^{\prime} 58^{\prime \prime} \mathrm{W}$ & $22 / 06 / 2017$ \\
\hline T41 & ABO42 & - & - & - \\
\hline T42 & $\mathrm{ABO} 43$ & - & - & - \\
\hline T43 & $\mathrm{ABO} 44$ & Assú-RN & $5^{\circ} 34^{\prime} 56^{\prime \prime} \mathrm{S} 36^{\circ} 56^{\prime} 40^{\prime \prime} \mathrm{W}$ & $22 / 03 / 2017$ \\
\hline
\end{tabular}




\begin{tabular}{ccccc}
\hline T44 & ABO47 & - & - & - \\
T45 & ABO48 & - & - & - \\
T46 & ABO49 & Ipanguaçu-RN & $5^{\circ} 28^{\prime} 31^{\prime \prime} \mathrm{S} 36^{\circ} 51^{\prime} 58^{\prime \prime} \mathrm{W}$ & $22 / 06 / 2017$ \\
T47 & $\mathrm{ABO50}$ & Ipanguaçu-RN & $5^{\circ} 28^{\prime} 31^{\prime \prime} \mathrm{S} 36^{\circ} 51^{\prime} 58^{\prime \prime} \mathrm{W}$ & $22 / 06 / 2017$ \\
T48 & $\mathrm{ABO51}$ & Assú-RN & $5^{\circ} 34^{\prime} 56^{\prime \prime} \mathrm{S} 36^{\circ} 56^{\prime} 40^{\prime \prime} \mathrm{W}$ & $22 / 03 / 2017$ \\
T49 & $\mathrm{ABO52}$ & Ipanguaçu-RN & $5^{\circ} 28^{\prime} 31^{\prime \prime} \mathrm{S} 36^{\circ} 51^{\prime} 58^{\prime \prime} \mathrm{W}$ & $22 / 06 / 2017$ \\
T50 & $\mathrm{CC}$ & Moranga Coroa ISLA ${ }^{\oplus 5}$ & - & - \\
T51 & $\mathrm{ABO55}$ & Assú-RN & $5^{\circ} 34^{\prime} 56^{\prime \prime} \mathrm{S} 36^{\circ} 56^{\prime} 40^{\prime \prime} \mathrm{W}$ & $22 / 03 / 2017$ \\
$\mathrm{~T} 52$ & $\mathrm{ABO56}$ & - & - & - \\
\hline
\end{tabular}

151 accessions of $C$. moschata Duch from the UFERSA cucurbit germplasm collection and a cultivar of $C$. maxima Duch obtained at the local market in Mossoró-RN. ${ }^{2}$ Access code in the UFERSA Cucurbitaceae germplasm collection. ${ }^{3}$ Place of origin of the access. ${ }^{4}$ Unknown procedure. ${ }^{5}$ Cultivar commercial obtained in local commerce (C. maxima Duch).

The UFERSA Cucurbitaceae germplasm collection is composed of thematic collections of other species besides $C$. maxima Duch. The accessions of $C$. maxima Duch studied in the present work come from traditional agriculture in the Northeast of Brazil, however, the sample represented in the study was collected in different mini principles in the State of Rio Grande do Norte.

\section{Experimental driving}

The seeds were sown in polystyrene trays with 128 cells, using one seed per cell and commercial substrate (Polifértil ${ }^{\oplus}$ ) for seedling production. The transplant was carried out when the seedlings had two to three definitive leaves.

The soil preparation consisted of plowing and harrowing. The drip irrigation system used was an adjustable drip in each plant with a flow rate of $18 \mathrm{~L} \mathrm{~h}^{-1}$, providing the blade according to the phenological stage of the crop. The combing of branches and weed control was carried out according to the recommendations for the crop.

The test was conducted in complete randomized blocks, with two replications and three plants per plot. The spacing used was $4.0 \mathrm{~m}$ between rows and $3.0 \mathrm{~m}$ between plants. After ripening, the fruits were harvested and sent to the post-harvest laboratory at the Center for Vegetable Research in the Semi-Arid region belonging to UFERSA for the characterization and evaluation from descriptors proposed by the Ministry of Agriculture, Livestock and Supply (Brasil 2004), in addition to others considered important in the evaluation of fruits.

The descriptors were as follows: fruit format (FF) - determined by the attribution of grades, with the aid of a format table: globular (1), flat (2), disc (3), oblong (4), elliptical (5), cordiform (6), pyriform (7), belted (8), elongated shapes (9), upper turbine (10), crowned (11), lower turbine (12), curved (13), twisted neck (14); apical shape (FA) and fruit base shape (FB): depressed (1), flat (2), protruding (3); the presence of recesses (buds) in the fruit (PG): absent (1), present (2); distance between recesses (buds) of the fruit (DG): short (3), medium (5), long (7); surface texture (TC): smooth (1), rough (2); warts (PV): absent (1), present (2); fruit mass (MF): obtained by weighing one fruit per plant. The fruits were weighed on a scale, accurate to $5 \mathrm{~g}$, and the result expressed in $\mathrm{kg}_{\text {fruit }}{ }^{-1}$; fruit length (FL): obtained by the longitudinal measurement of the fruit, with the aid of a graduated ruler and expressed in $\mathrm{cm}$; rind thickness (RT) and pulp thickness (PT): obtained by measuring with a graduated ruler and expressed in $\mathrm{cm}$. The fruits were sectioned longitudinally and the measurements were made on each side of one of the parts of the fruit, making the average of the measurements; diameter of the internal cavity $(\mathrm{Cl})$ : obtained by measuring the largest diameter of the internal cavity of the fruit, performed with the aid of a graduated ruler and expressed in cm; pulp firmness (PF): with the aid of a penetrometer and expressed in Newton; soluble solids (SS): measured using a digital refractometer and expressed in Brix; titratable acidity (TA): through titration with $0.1 \mathrm{~N} \mathrm{NaOH}$ and phenolphthalein indicator (1\%); Hydrogenionic potential $(\mathrm{pH})$ : reading with the aid of a $\mathrm{pH}$ meter. 


\section{Statistical analysis}

Initially, for the normally distributed quantitative characters, uni and multivariate analysis of variances were performed using the Snedecor F-test and the Wilks criterion at 5\% probability, respectively.

Due to the nature of the descriptors used for the study of diversity (qualitative and quantitative), different measures of dissimilarity (genetic distances) were used. For quantitative data, the standardized Euclidean distance was estimated from the matrix of means $(Z, \mu=0, \sigma=1)$. For qualitative data, as there was segregation between accessions, the index was used $\mathrm{d}_{\mathrm{ii}}=\left(\frac{1}{V} \sum_{j=1}^{v} \sum_{k=1}^{n_{j}} \frac{\delta_{k j}^{2}}{n_{j}}\right)^{0,5}$ to estimate dissimilarity as described in Cruz et al. (2011).

From the dissimilarity matrices, accessions were hierarchically grouped by the distance method by the arithmetic mean called UPGMA in English (Unweighted Pair Group Method with Arithmetic Mean). For the joint use of quantitative and qualitative descriptors, the two distance matrices were standardized based on the standard deviation of the distances in each matrix, as suggested by Cruz et al. (2011).

The choice of distance measurements and the grouping method was based on the correlation between the original distance matrix and the final grouping matrix, called the co-phenetic correlation. The relative contribution of quantitative characters to the divergence was also estimated using the criterion defined by Singh (1981).

The analysis was processed using the Genes program 2016 and the Pheatmap and Biotools (Silva et al. 2017) packages from Project R (R Core Team 2019).

\section{Results and Discussion}

There was an effect of accessions $(p<0.01$ or $p<0.05)$ for all characters in univariate analysis, indicating that there is heterogeneity between the accessions of the evaluated germplasm collection (Table 2).

Table 2. F values (Univariate), Wilks criterion (Multivariate) and grouping of pumpkin access averages for seven characters as Scott-Knott (1974).

\begin{tabular}{|c|c|c|c|c|c|c|c|c|c|}
\hline \multirow{2}{*}{ Access } & \multicolumn{9}{|c|}{ Average (Character) } \\
\hline & AFW & ST & PT & DIC & $\mathrm{FL}$ & $\mathrm{FP}$ & SS & AT & $\mathrm{pH}$ \\
\hline AB-01 & $2.33^{a}$ & $0.23^{a}$ & $2.30^{b}$ & $10.84^{b}$ & $18.92^{\mathrm{b}}$ & $65.16^{b}$ & $6.19^{b}$ & $0.17^{b}$ & $6.30^{\mathrm{a}}$ \\
\hline AB-02 & $2.86^{a}$ & $0.25^{\mathrm{a}}$ & $3.65^{a}$ & $9.00^{b}$ & $20.10^{b}$ & $99.83^{a}$ & $4.90^{b}$ & $0.31^{b}$ & $5.94^{b}$ \\
\hline AB-03 & $2.22^{\mathrm{a}}$ & $0.22^{a}$ & $2.50^{b}$ & $12.24^{\mathrm{a}}$ & $12.79^{c}$ & $48.72^{c}$ & $9.05^{a}$ & $0.30^{b}$ & $5.92^{b}$ \\
\hline AB-04 & $2.15^{\mathrm{a}}$ & $0.18^{b}$ & $2.39^{b}$ & $8.85^{b}$ & $18.70^{\mathrm{b}}$ & $43.40 d$ & $7.50^{\mathrm{b}}$ & $0.27^{b}$ & $6.15^{a}$ \\
\hline AB-05 & $1.81^{\mathrm{a}}$ & $0.23^{a}$ & $2.35^{b}$ & $8.39^{b}$ & $20.87^{b}$ & $57.26^{c}$ & $11.12^{\mathrm{a}}$ & $0.44^{a}$ & $5.96^{b}$ \\
\hline AB-06 & $1.34^{\mathrm{a}}$ & $0.15^{b}$ & $2.29^{b}$ & $9.45^{b}$ & $15.60^{c}$ & $54.73^{c}$ & $7.43^{b}$ & $0.27^{b}$ & $6.07^{\mathrm{a}}$ \\
\hline AB-07 & $2.62^{\mathrm{a}}$ & $0.15^{b}$ & $2.64^{b}$ & $9.67^{b}$ & $23.84^{\mathrm{b}}$ & $64.89^{b}$ & $6.29^{b}$ & $0.20^{b}$ & $6.15^{\mathrm{a}}$ \\
\hline AB-08 & $1.31^{\mathrm{a}}$ & $0.19^{b}$ & $1.98^{b}$ & $10.25^{b}$ & $12.75^{c}$ & $64.24^{b}$ & $8.03^{b}$ & $0.29^{b}$ & $6.26^{a}$ \\
\hline AB-09 & $1.44^{\mathrm{a}}$ & $0.22^{a}$ & $2.31^{b}$ & $9.62^{b}$ & $14.02^{c}$ & $92.86^{a}$ & $9.04^{a}$ & $0.33^{b}$ & $5.97^{b}$ \\
\hline$A B-10$ & $1.52^{\mathrm{a}}$ & $0.25^{a}$ & $1.60^{b}$ & $10.80^{\mathrm{b}}$ & $19.75^{b}$ & $58.58^{c}$ & $6.07^{b}$ & $0.19^{b}$ & $6.24^{\mathrm{a}}$ \\
\hline AB-11 & $1.74^{a}$ & $0.33^{a}$ & $1.52^{b}$ & $11.55^{a}$ & $15.88^{c}$ & $77.72^{b}$ & $6.92^{b}$ & $0.29^{b}$ & $6.26^{\mathrm{a}}$ \\
\hline$A B-12$ & $1.62^{\mathrm{a}}$ & $0.33^{a}$ & $1.87^{b}$ & $11.76^{a}$ & $12.00^{c}$ & $68.67^{b}$ & $7.31^{b}$ & $0.27^{b}$ & $6.25^{a}$ \\
\hline$A B-13$ & $1.81^{a}$ & $0.28^{a}$ & $2.47^{b}$ & $10.50^{b}$ & $16.38^{c}$ & $83.68^{b}$ & $7.77^{b}$ & $0.42^{a}$ & $6.12^{\mathrm{a}}$ \\
\hline AB-14 & $2.45^{\mathrm{a}}$ & $0.18^{b}$ & $2.93^{a}$ & $11.55^{\mathrm{a}}$ & $20.75^{b}$ & $53.91^{c}$ & $7.81^{b}$ & $0.31^{b}$ & $6.12^{\mathrm{a}}$ \\
\hline$A B-15$ & $1.86^{\mathrm{a}}$ & $0.25^{\mathrm{a}}$ & $2.67^{b}$ & $9.07^{b}$ & $13.50^{c}$ & $46.94^{d}$ & $6.00^{b}$ & $0.31^{b}$ & $6.08^{\mathrm{a}}$ \\
\hline AB-16 & $4.50^{a}$ & $0.24^{a}$ & $3.52^{\mathrm{a}}$ & $13.50^{\mathrm{a}}$ & $19.33^{b}$ & $64.24^{b}$ & $7.32^{b}$ & $0.25^{b}$ & $6.25^{a}$ \\
\hline$A B-17$ & $1.32^{\mathrm{a}}$ & $0.23^{a}$ & $1.97^{b}$ & $9.98^{b}$ & $12.48^{c}$ & $49.14^{c}$ & $7.92^{b}$ & $0.25^{b}$ & $6.35^{a}$ \\
\hline AB-18 & $0.68^{a}$ & $0.20^{b}$ & $1.70^{b}$ & $8.15^{b}$ & $9.30^{c}$ & $68.42^{\mathrm{b}}$ & $8.85^{a}$ & $0.43^{a}$ & $6.08^{a}$ \\
\hline AB-19 & $1.20^{\mathrm{a}}$ & $0.25^{\mathrm{a}}$ & $2.15^{b}$ & $11.27^{a}$ & $10.97^{c}$ & $72.33^{b}$ & $7.72^{\mathrm{b}}$ & $0.25^{b}$ & $6.36^{a}$ \\
\hline$A B-20$ & $1.52^{\mathrm{a}}$ & $0.20^{b}$ & $2.33^{b}$ & $11.02^{\mathrm{a}}$ & $11.47^{c}$ & $53.63^{c}$ & $5.37^{b}$ & $0.21^{b}$ & $6.23^{\mathrm{a}}$ \\
\hline$A B-21$ & $1.44^{a}$ & $0.13^{b}$ & $2.20^{\mathrm{b}}$ & $9.70^{b}$ & $14.33^{c}$ & $42.03 d$ & $6.47^{b}$ & $0.23^{b}$ & $6.21^{\mathrm{a}}$ \\
\hline AB-22 & $1.52^{\mathrm{a}}$ & $0.11^{b}$ & $2.16^{\mathrm{b}}$ & $11.76^{a}$ & $10.11^{\mathrm{c}}$ & $68.47^{b}$ & $12.10^{\mathrm{a}}$ & $0.49^{a}$ & $6.15^{\mathrm{a}}$ \\
\hline
\end{tabular}




\begin{tabular}{|c|c|c|c|c|c|c|c|c|c|}
\hline AB-23 & $2.38^{a}$ & $0.33^{a}$ & $2.70^{b}$ & $11.70^{\mathrm{a}}$ & $14.43^{c}$ & $37.13^{d}$ & $5.58^{b}$ & $0.20^{b}$ & $6.26^{\mathrm{a}}$ \\
\hline AB-24 & $2.31^{\mathrm{a}}$ & $0.23^{a}$ & $3.44^{\mathrm{a}}$ & $8.99^{b}$ & $17.59^{c}$ & $63.56^{b}$ & $8.30^{\mathrm{a}}$ & $0.37^{a}$ & $5.99^{b}$ \\
\hline$A B-25$ & $3.02^{a}$ & $0.33^{a}$ & $3.01^{a}$ & $14.37^{a}$ & $10.35^{c}$ & $53.30^{c}$ & $6.75^{b}$ & $0.20^{\mathrm{b}}$ & $6.24^{\mathrm{a}}$ \\
\hline AB-26 & $1.25^{a}$ & $0.22^{\mathrm{a}}$ & $1.43^{b}$ & $9.53^{b}$ & $17.01^{c}$ & $35.63^{d}$ & $7.20^{\mathrm{b}}$ & $0.33^{b}$ & $6.18^{\mathrm{a}}$ \\
\hline$A B-27$ & $3.03^{a}$ & $0.20^{b}$ & $3.02^{a}$ & $12.03^{a}$ & $18.00^{\mathrm{b}}$ & $72.19^{b}$ & $6.40^{\mathrm{b}}$ & $0.27^{b}$ & $6.16^{a}$ \\
\hline AB-28 & $2.35^{a}$ & $0.20^{b}$ & $2.31^{b}$ & $10.24^{b}$ & $21.49^{b}$ & $77.86^{\mathrm{b}}$ & $8.98^{a}$ & $0.34^{b}$ & $6.00^{b}$ \\
\hline AB-29 & $3.00^{a}$ & $0.27^{a}$ & $2.84^{b}$ & $11.58^{\mathrm{a}}$ & $21.70^{b}$ & $59.03^{c}$ & $8.53^{a}$ & $0.33^{b}$ & $6.15^{\mathrm{a}}$ \\
\hline AB-30 & $2.68^{a}$ & $0.23^{a}$ & $2.46^{\mathrm{b}}$ & $11.55^{\mathrm{a}}$ & $19.77^{b}$ & $66.56^{b}$ & $4.39^{b}$ & $0.25^{b}$ & $6.15^{\mathrm{a}}$ \\
\hline AB-31 & $2.32^{\mathrm{a}}$ & $0.37^{a}$ & $2.29^{b}$ & $12.44^{\mathrm{a}}$ & $14.79^{c}$ & $71.99^{b}$ & $7.68^{b}$ & $0.31^{b}$ & $5.97^{b}$ \\
\hline AB-32 & $1.87^{\mathrm{a}}$ & $0.32^{\mathrm{a}}$ & $2.57^{b}$ & $11.83^{\mathrm{a}}$ & $11.55^{\mathrm{c}}$ & $54.43^{c}$ & $7.48^{b}$ & $0.32^{\mathrm{b}}$ & $6.32^{\mathrm{a}}$ \\
\hline AB-33 & $2.90^{\mathrm{a}}$ & $0.23^{a}$ & $2.55^{b}$ & $10.10^{\mathrm{b}}$ & $25.10^{b}$ & $56.94^{c}$ & $6.90^{\mathrm{b}}$ & $0.26^{b}$ & $5.89^{b}$ \\
\hline AB-34 & $1.60^{\mathrm{a}}$ & $0.37^{a}$ & $2.79^{b}$ & $9.15^{b}$ & $11.60^{c}$ & $86.31^{b}$ & $9.50^{a}$ & $0.37^{a}$ & $6.15^{\mathrm{a}}$ \\
\hline AB-35 & $2.90^{\mathrm{a}}$ & $0.25^{a}$ & $1.95^{\mathrm{b}}$ & $9.55^{b}$ & $34.55^{\mathrm{a}}$ & $74.81^{b}$ & $10.40^{\mathrm{a}}$ & $0.32^{\mathrm{b}}$ & $5.97^{b}$ \\
\hline AB-36 & $3.06^{a}$ & $0.25^{a}$ & $2.73^{b}$ & $11.93^{a}$ & $12.60^{\circ}$ & $69.43^{b}$ & $8.90^{a}$ & $0.35^{a}$ & $5.88^{b}$ \\
\hline AB-37 & $2.26^{a}$ & $0.30^{a}$ & $2.39^{b}$ & $11.28^{\mathrm{a}}$ & $15.65^{c}$ & $78.99^{b}$ & $9.93^{a}$ & $0.37^{a}$ & $6.12^{a}$ \\
\hline AB-38 & $2.12^{\mathrm{a}}$ & $0.20^{b}$ & $1.90^{\mathrm{b}}$ & $13.00^{\mathrm{a}}$ & $13.50^{c}$ & $69.28^{b}$ & $9.50^{\mathrm{a}}$ & $0.41^{a}$ & $5.79^{b}$ \\
\hline AB-39 & $4.85^{a}$ & $0.22^{\mathrm{a}}$ & $3.68^{a}$ & $12.78^{\mathrm{a}}$ & $21.88^{b}$ & $51.97^{c}$ & $6.43^{b}$ & $0.30^{\mathrm{b}}$ & $6.08^{a}$ \\
\hline AB-40 & $4.08^{a}$ & $0.15^{b}$ & $3.25^{\mathrm{a}}$ & $12.33^{\mathrm{a}}$ & $32.23^{\mathrm{a}}$ & $47.18^{d}$ & $5.32^{b}$ & $0.19^{b}$ & $6.15^{a}$ \\
\hline AB-41 & $2.52^{\mathrm{a}}$ & $0.15^{b}$ & $3.85^{a}$ & $12.00^{\mathrm{a}}$ & $11.50^{c}$ & $47.10^{d}$ & $7.10^{\mathrm{b}}$ & $0.39^{a}$ & $6.40^{\mathrm{a}}$ \\
\hline AB-42 & $3.73^{a}$ & $0.45^{a}$ & $4.48^{a}$ & $11.70^{\mathrm{a}}$ & $11.45^{c}$ & $83.65^{b}$ & $10.45^{\mathrm{a}}$ & $0.50^{a}$ & $6.28^{a}$ \\
\hline AB-43 & $3.25^{a}$ & $0.24^{a}$ & $2.63^{b}$ & $10.66^{b}$ & $22.83^{b}$ & $60.87^{c}$ & $7.12^{\mathrm{b}}$ & $0.29^{b}$ & $5.97^{b}$ \\
\hline AB-44 & $1.69^{a}$ & $0.28^{a}$ & $2.30^{\mathrm{b}}$ & $10.28^{b}$ & $15.59^{c}$ & $65.64^{b}$ & $7.59^{b}$ & $0.32^{\mathrm{b}}$ & $6.07^{\mathrm{a}}$ \\
\hline AB-45 & $2.37^{a}$ & $0.18^{b}$ & $2.39^{b}$ & $9.95^{b}$ & $24.15^{b}$ & $65.71^{b}$ & $8.27^{a}$ & $0.29^{b}$ & $5.42^{\mathrm{b}}$ \\
\hline AB-46 & $2.05^{a}$ & $0.10^{b}$ & $2.53^{b}$ & $9.20^{b}$ & $20.40^{\mathrm{b}}$ & $66.89^{b}$ & $7.05^{b}$ & $0.34^{\mathrm{b}}$ & $6.37^{\mathrm{a}}$ \\
\hline AB-47 & $1.67^{a}$ & $0.34^{\mathrm{a}}$ & $1.83^{b}$ & $7.63^{b}$ & $21.38^{b}$ & $91.15^{\mathrm{a}}$ & $8.37^{a}$ & $0.49^{a}$ & $6.16^{a}$ \\
\hline AB-48 & $1.65^{a}$ & $0.24^{a}$ & $2.17^{b}$ & $10.36^{\mathrm{b}}$ & $16.19^{c}$ & $59.68^{c}$ & $7.94^{b}$ & $0.29^{b}$ & $6.06^{a}$ \\
\hline AB-49 & $4.55^{a}$ & $0.20^{b}$ & $3.10^{\mathrm{a}}$ & 16.50 ạ & $17.60^{c}$ & $54.43^{c}$ & $5.40^{\mathrm{b}}$ & $0.23^{b}$ & $6.00^{b}$ \\
\hline$A B-50$ & $1.05^{a}$ & $0.13^{b}$ & $2.18^{\mathrm{b}}$ & $10.83^{b}$ & $8.83^{c}$ & $44.94^{d}$ & $4.15^{b}$ & $0.13^{b}$ & $6.29^{a}$ \\
\hline$A B-51$ & $3.81^{\mathrm{a}}$ & $0.28^{a}$ & $3.20^{\mathrm{a}}$ & $9.75^{b}$ & $25.10^{\mathrm{b}}$ & $73.89^{b}$ & $10.43^{a}$ & $0.37^{a}$ & $6.21^{a}$ \\
\hline $\mathrm{CC}$ & $2.32^{\mathrm{a}}$ & $0.31^{a}$ & $2.77^{b}$ & $11.00^{\mathrm{a}}$ & $13.00^{c}$ & $71.36^{b}$ & $9.34^{\mathrm{a}}$ & $0.43^{a}$ & $6.09^{a}$ \\
\hline \multicolumn{10}{|c|}{ ANOVA } \\
\hline \multicolumn{10}{|c|}{ Snedecor's F (Trait) } \\
\hline Acess & $1.82^{*}$ & $1.71^{*}$ & $2.88^{* *}$ & $2.65^{* *}$ & $3.51^{* *}$ & $2.74^{* *}$ & $3.27^{* *}$ & $3.42^{* *}$ & $2.72^{* *}$ \\
\hline CV (\%) & 42.45 & 32.62 & 20.19 & 13.02 & 24.43 & 19.14 & 17.42 & 20.93 & 2.4 \\
\hline Wilks & $2.25^{* *}$ & & & & & & & & \\
\hline
\end{tabular}

**, *: Significant at 1 and 5\% probability by the F of Snedecor. AFW: average fruit weight (g); ST: shell thickness (cm); PT: pulp thickness $(\mathrm{cm})$; DIC: diameter of the internal cavity $(\mathrm{cm})$; FL: fruit length $(\mathrm{cm})$; FP: firmness of the pulp (N); SS: soluble solids (\%); AT: titratable acidity; $\mathrm{pH}$ : hydrogen potential. The letters $\mathrm{a}, \mathrm{b}, \mathrm{c}$ and $\mathrm{d}$ refer to the groups formed in the clustering of means obtained by the UPGMA method.

Despite the existence of differences between accessions, it was found that the variability is not accentuated when the averages of accessions were grouped by the Scott-Knott (1974) methodology. For the average weight of the fruit (AFW), there was no discrimination between the liters, probably due to the lower experimental precision for this character. This fact is reinforced when verifying the amplitude of $4.17 \mathrm{~kg}$ due to the difference between the highest fruit weight $(4.85 \mathrm{~kg})$ in the AB-39 access and the smallest $(0.68 \mathrm{~kg})$ in the AB-18 access (Table 2).

An important first aspect to be considered in the evaluation and characterization of a large number of accessions in field conditions is the experimental precision (Borges et al. 2011; Oliveira et al. 2016). In the present work, considering that the experimental precision is traditionally measured by the coefficient of variation (Ferreira et al. 2016), it was found that the estimates were relatively high mainly for the average weight of the fruit and thickness of the skin. However, for all characters, it was possible to detect differences between accessions. Another aspect to be considered is the need to have, like other cultures, a classification of coefficients of variation for the pumpkin in order to have greater security in the evaluation of the 
experimental quality (Silva et al. 2011; Ferreira et al. 2016). Heterogeneity is indicated by the coefficient of variation, and higher values, and variation values, indicate greater variability (Singh et al. 2017; Borges et al. 2019).

In the case of pumpkins, whose plants have indeterminate growth and occupy a large area of the area that needs to be uniform, one of the great challenges is to evaluate the largest possible number of accessions in trials with good experimental quality. Another difficulty is that the number of seeds per access is often reduced. In this scenario, the use of many repetitions with plots made up of some plants is almost impossible. An alternative to being tested in future evaluations is to use plots of a plant and to increase the number of repetitions as is done in perennial crops and, or incomplete block designs (Resende 2007).

Concerning the thickness of the bark, the first group was composed of 34 accessions with averages ranging from 0.22 to $0.45 \mathrm{~cm}$ while the second, composed of 18 accessions, the averages were between 0.10 to $0.22 \mathrm{~cm}$. For the pulp thickness, the group of highest averages $(2.93$ to $4.48 \mathrm{~cm})$ was formed by 12 accessions while the group of lowest averages ( 1.43 to 2.84 ) by 40 , totaling $76.92 \%$ of accessions (Table 2 ).

Two groups were formed for the diameter of the internal cavity, one composed of 24 and the other by 28 accessions. The group with the lowest number of accessions had the highest averages (11.0 to 16.50 $\mathrm{cm}$ ) while the largest group had the lowest averages $(7.63$ to $10.84 \mathrm{~cm})$. For the length of the fruit, the accessions were divided into three groups. In the first group, composed of only two accessions, it allocated the largest lengths of fruit with averages 32.23 and $34.55 \mathrm{~cm}$. The second, composed of 19 accessions, had averages ranging from 18.0 to $25.10 \mathrm{~cm}$. In the third and largest group, with 31 condensed accessions, the lowest averages were found (17.6 to 8.83) (Table 2).

The greatest discrimination of accessions occurred for the firmness of the pulp. For that variable, four groups were formed with $3,26,15$, and 8 accessions. The first group was formed only by three accessions and contemplated the greatest firmness $(A B-02=99.83 ; A B-09=92.86$ and $A B-47=91.15 N)$. The second group was the largest with 26 accessions and averages ranging from 63.56 to $86.31 \mathrm{~N}$. The third and fourth groups, with 14 and 8 accessions, respectively, the smallest with the lowest average firmness of pulp ( 35.63 a $47.18 \mathrm{~N}$ ) (Table 2).

Regarding soluble solids, the two groups consisted of 18 and 34 accessions (Table 2). The smallest group allocated accessions with the highest averages ( 8.27 to 12.10 Brix) while the largest with the smallest (4.15 to 8.03 oBrix).

The accessions were grouped into two groups for the variable's titratable acidity and hydrogen potential. For the first variable, the first group consisted of 14 accessions with the highest averages $(0.35$ to $0.5 \%)$ while in the second, 38 accessions with the lowest averages (0.13 to $0.34 \%$ ). In the second variable, the opposite was observed, that is, in the first group, with the highest averages (6.06 to 6.40), 38 accessions were added against 14 in the second group, consisting of the accessions with the lowest average values (5.42 to 6.0).

When all characters were considered simultaneously (multivariate analysis), an access effect was also observed $(p<0.01)$ (Table 2 ).

From the dissimilarity matrix, accessions were grouped into eight groups (Figure $2 \mathrm{~A}$ ). The accessions $A B-42$ and $A B-45$ each formed the first two-unit groups. The third group consisted of only accessions $A B-40$, $A B-49, A B-16$, and $A B-39$. The fourth group allocated only AB-02 access; and the fifth, the AB-47 accessions. $A B-35$ and $A B-51$. Accessions $A B-18$ and $A B-22$ were allocated to the sixth group. The seventh was also unitary, with only $A B-41$; and the last group was composed of the other accessions. It is noteworthy that the estimate of the cophenetic correlation was $r=0.75^{* *}$, Indicating reliability in the matrices obtained from the original and final distance, that is, there was a reduction in the loss of information through the hierarchical grouping process via UPGMA. 
A

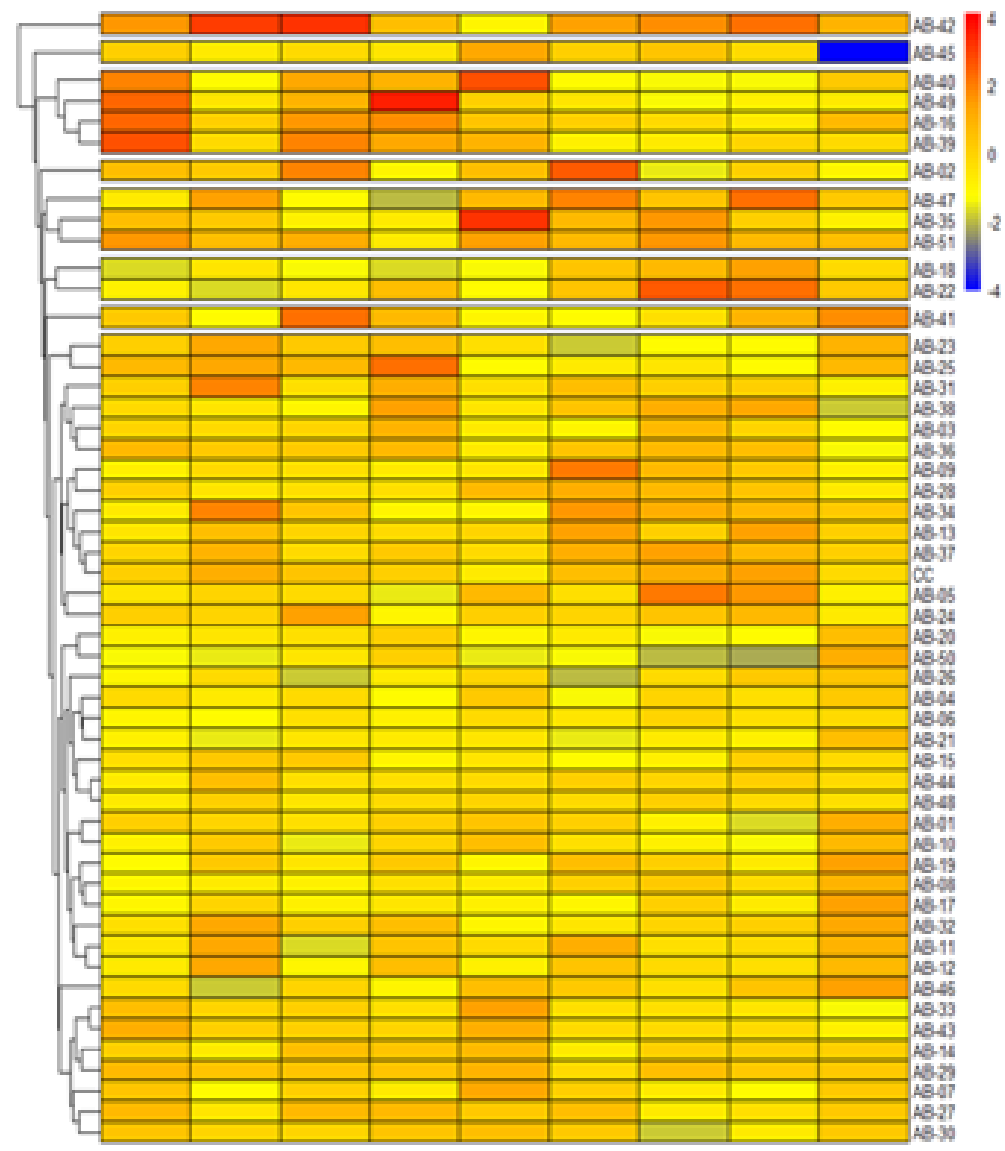

B

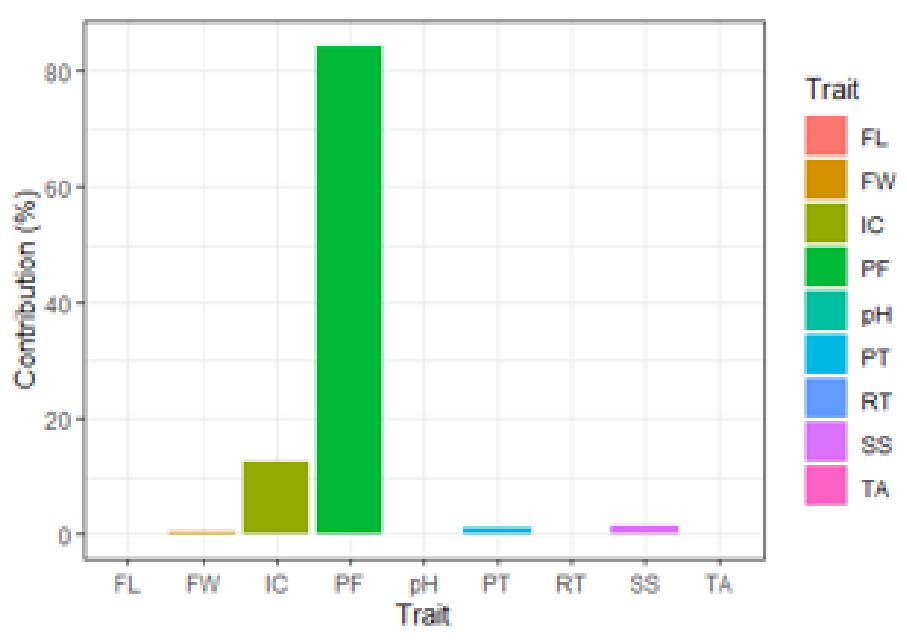

Figure 2. A - dendrogram generated by the UPGMA method from the standardized Euclidean distance; B contribution of each quantitative descriptor (\%) to the genetic divergence between pumpkin accessions (Singh 1981). Cophenetic correlation $\left(r=0.75^{* *}\right)$. FW: fruit weight (g); RT: rind thickness (cm); PT: pulp thickness $(\mathrm{cm})$; IC: diameter of the internal cavity $(\mathrm{cm})$; FL: fruit length $(\mathrm{cm})$; PF: firmness of the pulp (N);

SS: soluble solids (\%); TA: titratable acidity; $\mathrm{pH}$ : hydrogen potential.

The breakdown of accessions in eight groups, at first, would indicate a great variability in the evaluated germplasm. However, this fact did not occur since $50 \%$ of the groups formed (four) were constituted by only one access, another three groups were composed of two to four accessions and, mainly because more than $75 \%$ of the accessions were gathered in only one group.

This result was not expected since Rio Grande do Norte is one of the main national producers and gathers a great genetic variability for plant and fruit descriptors as reported by Lima et al. (2016). These authors recovered accessions of $C$. moschata in 11 municipalities and observed a wide range of variation for fruit weight, fruit length, pulp thickness, fruit diameter, soluble solids, and other quantitative descriptors. Other studies with $C$. moschata showed greater genetic variability, however, the studies consulted included more accessions from different ecogeographic sources (Ramos et al. 2000; Borges et al. 2011; Oliveira et al. 
2016). A possible reason for the lower variability verified in this investigation is the fact that the collection is composed of accessions from only one state of the federation. Therefore, it is a reduced collection in terms of the number of accessions and sampled locations.

Another important aspect is to know where the genetic divergence is concentrated in terms of variables. In other words, which variables contributed most to the heterogeneity between accessions. From Figure $2 \mathrm{~B}$, it is easy to see that the variables that most contributed to the divergence were the firmness of the pulp (84.52\%) and fruit length (FL) (12.64\%), which totaled practically all the genetic divergence (97.16\%). The last seven variables concentrated only $2.84 \%$ of the divergence. Therefore, it appears that there is not much variability between accessions and that the existing variability is accumulated in only two variables, firmness of the pulp and length of the fruit.

Regarding the firmness of the pulp, little information was found in the consulted literature. Amariz (2011) observed heterogeneity between C. moschata accessions with amplitude and variation greater than the present study. Amariz (2011) found that among 15 quantitative descriptors, evaluated in 15 accessions of $C$. moschata, the firmness of the pulp was the sixth of greatest contribution with $5.10 \%$ of the genetic divergence. Although not common, the firmness of the pulp must always be considered when evaluating and characterizing pumpkin germplasm because it is associated with the potential for storage and transportation of the fruits. Fruits with greater firmness have greater durability and resistance to transport. Many fruits produced in the Northeast are sold in other states such as Espírito Santo and Rio de Janeiro (Ramos et al. 2000).

For fruit length, Ramos et al. (2000), Amariz (2011) and Borges et al. (2011), in C. moschata; and Balkaya et al. (2010), verified in C. maximum that the length of the fruit was among the variables that most contributed to the divergence. Although it did not measure the contribution of the length of the fruit to the divergence in relation to the other variables, Lima et al. (2016) observed a total amplitude in 112 accessions of $C$. moschata similar to that of this study. These facts reinforce the presence of variability between accessions for that character. The length of the fruit is one of the important variables for commercialization. Therefore, many farmers make selection according to the local consumer market.

Considering the qualitative descriptors of the fruit used in this work, the formation of six groups of accessions was observed. $A$ unitary group represented by the access $A B-50$, two smaller groups, one composed of the accessions $A B-38, A B-41$ and $A B-49$; and another for $A B-22, A B-12, A B-20$, and $A B-25$. And two other larger groups, one consisting of 20 accessions (38.5\%) and the other of 24 accessions (46.2\%) (Figure 3). The co-phenetic correlation estimate $\left(0.71^{* *}\right)$ confirmed the reliability in the cluster. 


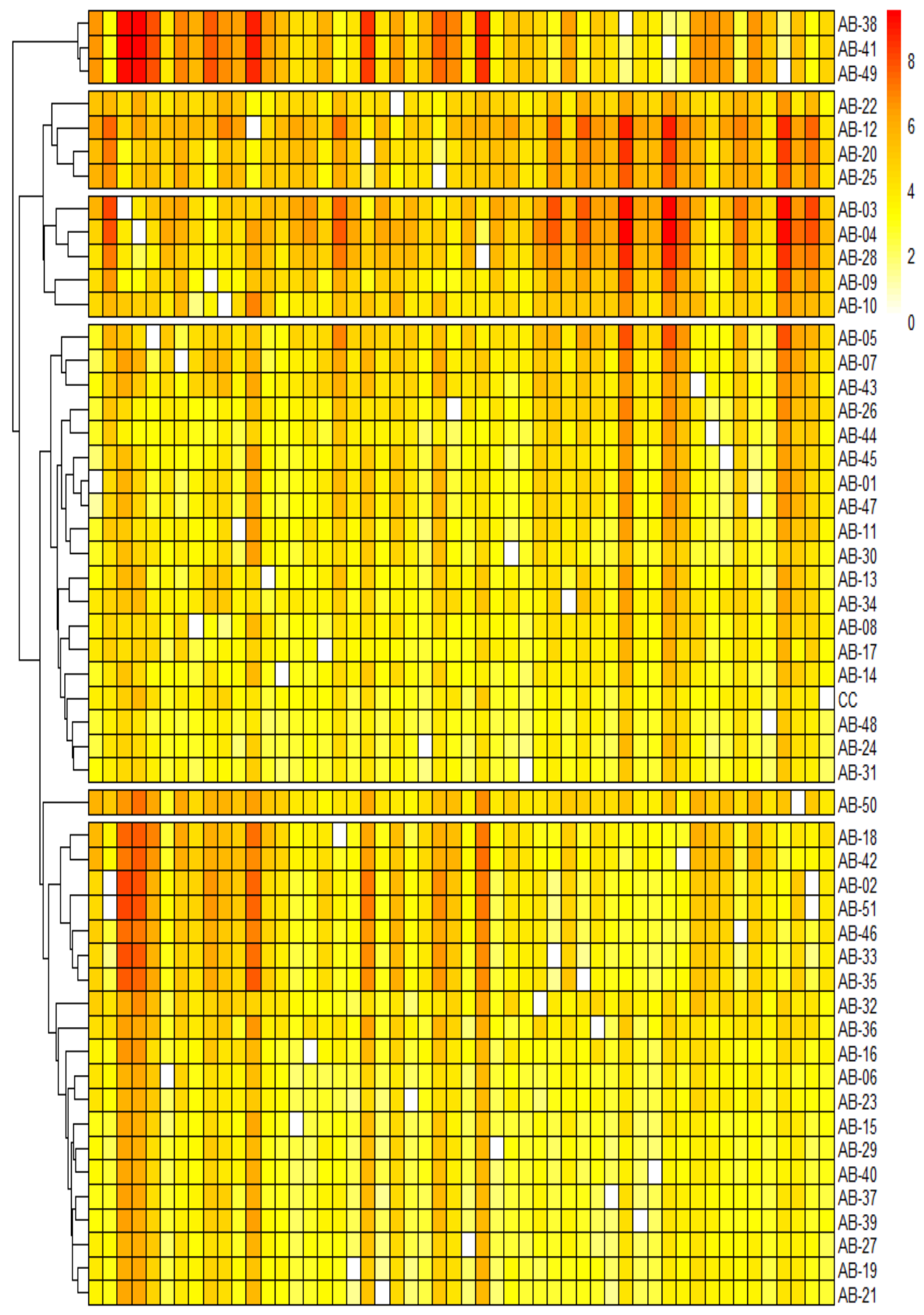

Figure 3. Dendrogram generated by the UPGMA method from the distance generated for qualitative descriptors of the fruit evaluated in pumpkin accessions. Cophenetic correlation $\left(r=0.71^{* *}\right)$.

The variation between accessions for the descriptors was greater for the characters related to the fruit shape, base, and apical shapes. Nine types of fruit shapes were observed. The most common formats were FF1 (globular), FF6 (cordiform) and FF5 (elliptical) (Figure 3, in orange). Only the AB-04 access has FF10 fruits (upper turbine). Nine accessions exhibited only one type of fruit, indicating variability within the accessions for this variable (Figure 4). 


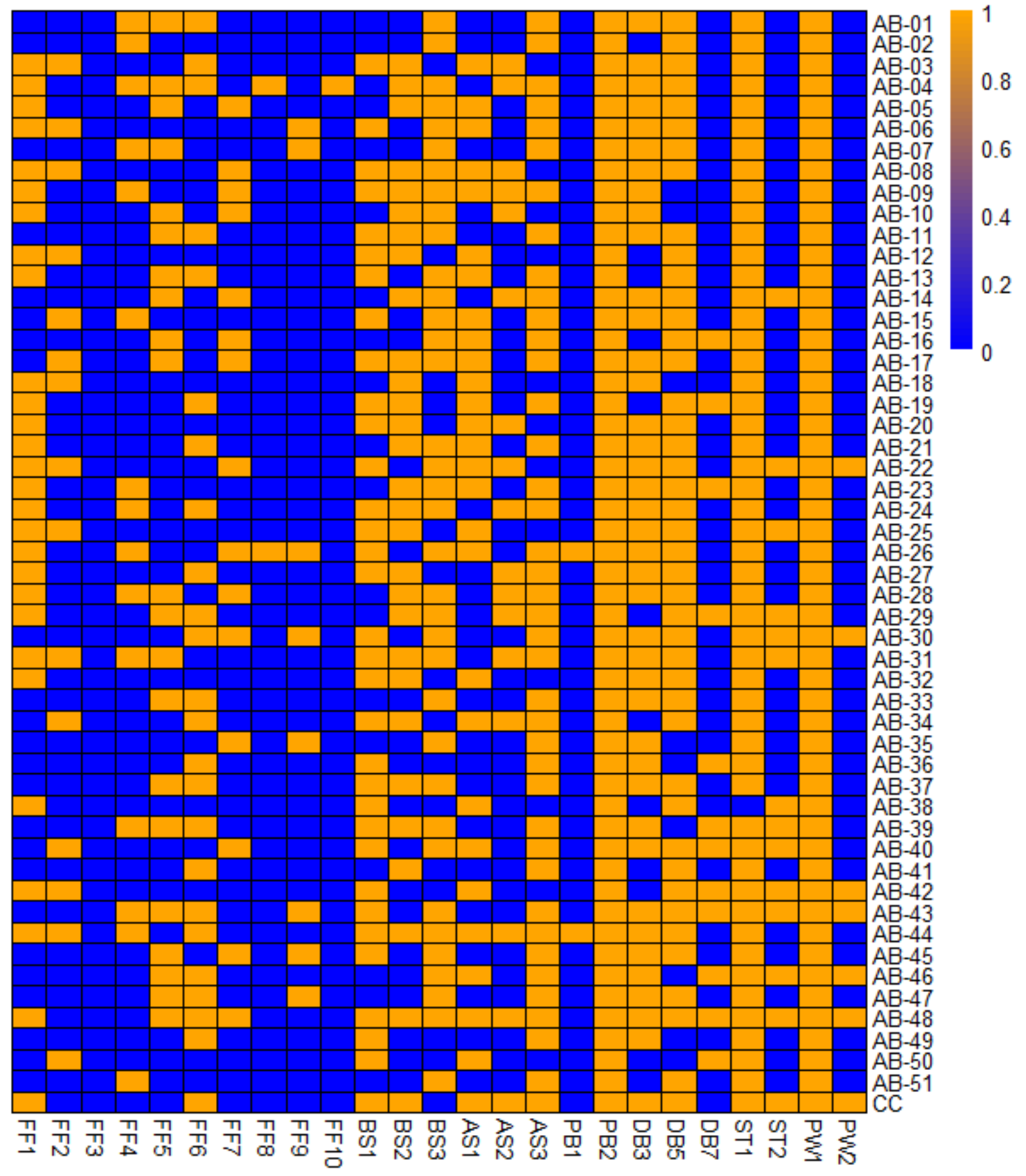

Figure 4. Presence (orange) and absence (blue) of characteristics in descriptors of the fruit of pumpkin accessions. fruit format (FF): globular (FF1), flat (FF2), disc (FF3), oblong (FF4), elliptical (FF5), cordiform (FF6), pyriform (FF7), belted (FF8), elongated shapes (FF9), upper turbine (FF10); fruit basal shape(FA): depressed (FA1), flat (FA2), protruding (FA3); fruit apical shape (FB): depressed (FB1), flat (FB2), protruding (FB3); presence of recesses (buds) in the fruit (PB): absent (PB1), present (PB2); distance between recesses (buds) of the fruit (DG): short (DB3), medium (DB5), long (DB7); surface texture (ST): smooth (ST1), rough (ST2); warts (PW): absent (PW1), present (PW2).

Regarding the shape of the fruit base, most accessions (50\%) have two forms and only ten of the three possible forms. The BS1 and BS3 forms were the most common among the accessions. For the apical shape, the type of fruit AS3 (protuberant) predominated in $76.92 \%$ of the accessions. The percentage of accessions that have one or two types of fruit apical was $90.38 \%$, against only $9.62 \%$ of accessions with three apical formats of the fruit (Figure 4).

All accessions have fruit with buds, most of which have an average distance between them (DG5). Only four accessions have fruits with three distances: small (DG3), medium (DG5), and large (DG7) between the buds, namely, $A B-23, A B-40, A B-43$, and $A B-48$. Thirty-nine accessions have only one type of fruit texture, 
with a predominance of smooth (ST1). The absence of warts in the fruits was observed in nearly all accessions, but some fruits of the AB-22, AB-30, AB-42, AB-43, AB-46, AB-48, and AB-CC accessions have warts (Figure 4).

The Northeast region has been highlighted as an area that concentrates great genetic variability (Esquinas-Alcazar and Gullick 1983). It appears that in that region there is a wide variation in the shape of the fruit and other characters in C. moschata (Ramos et al. 2000; Borges et al. 2011; Ramos et al. 2010; Blank et al. 2013). Nine of the 14 formats mentioned in the literature were observed, the most common being globular, cordiform, and elliptical. Lima et al. (2016) observed globular, flat, oblong, elliptical, cordiform, pyriform, and elongated shapes. Oliveira et al. (2016) described globular, pyriform, elliptical cordiform fruits in accessions from northern Rio de Janeiro. In C. máxima, Balkaya et al. (2010), found that the greatest variation in accessions was in the shape of the fruit with the highest frequency of globular fruits.

The shape of the fruit, together with the colors of the skin and pulp, are important characters for the consumer due to the visual appeal. For this reason, it receives a lot of attention from farmers. Selection by the shape of the fruit allows the generation of Creole varieties selected and maintained based on the demands of the consumer markets and grown under specific edaphoclimatic conditions (Ramos et al. 2010). In addition, in some situations, the farmer selects by his own consumption preference. This allows the allelic fixation to the character and generates more uniform materials.

The grouping obtained from the combined information from the qualitative and quantitative descriptors generated eight groups of accessions. Fifteen accessions (28.85\%) were distributed in five smaller groups, composed of five (AB-48, CC, $A B-29, A B-39, A B-40)$, four ( $A B-30, A B-43, A B-35, A B-47)$, three ( $A B-42, A B-38, A B-50)$, two (AB-16, AB-46) and one component (AB-2). The remaining 37 accessions (71.15\%) were gathered in three more groups, consisting of nine, twelve, and sixteen materials (Figure 5). Again, the grouping can be considered reliable since the cophenetic correlation estimate was greater than 0.70 . 


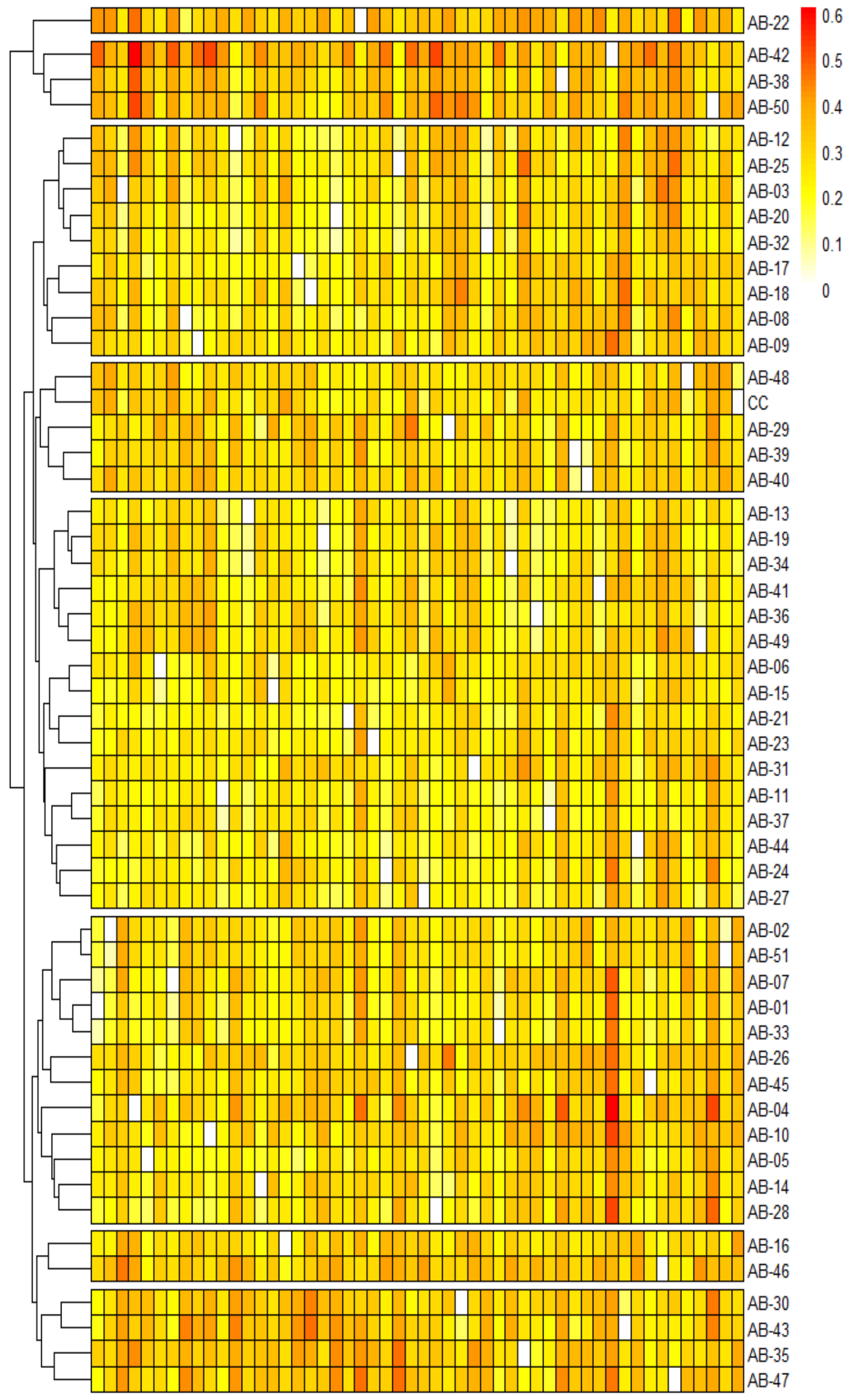

Figure 5. Dendrogram generated by UPGMA from the matrix obtained by the average of the standardized distances of the quantitative and qualitative descriptors evaluated in pumpkin accessions. Cophenetic correlation $\left(r=0.76^{* *}\right)$. 
Table 3 shows the average data for the quantitative descriptors and the total number for the qualitative ones in the groups formed. It was found that the groups had similar averages for all quantitative descriptors. However, some differences can be mentioned for smaller fruits in groups III and VIII, less skin thickness in group VIII, shorter fruit lengths in groups III, VI, and VIII, greater pulp firmness in group V, greater soluble solids in the group VIII, greater acidity in group VIII. It is noteworthy that group eight was composed only by access AB-22 (Figure 5 ).

Table 3. Averages of quantitative descriptors and total of qualitative descriptors in different groups of pumpkin accessions.

\begin{tabular}{|c|c|c|c|c|c|c|c|c|c|}
\hline \multirow{2}{*}{ Descriptors } & \multicolumn{8}{|c|}{ Group } & \multirow{2}{*}{ Average } \\
\hline & I (16) & II (12) & III (9) & IV (5) & $\mathrm{V}(4)$ & VI (3) & VII (2) & VIII (1) & \\
\hline FW & 2.19 & 2.37 & 1.67 & 3.18 & 2.63 & 2.30 & 3.28 & 1.52 & 2.39 \\
\hline ST & 0.25 & 0.22 & 0.25 & 0.24 & 0.27 & 0.26 & 0.17 & 0.11 & 0.22 \\
\hline PT & 2.62 & 2.48 & 2.25 & 2.94 & 2.22 & 2.85 & 3.03 & 2.16 & 2.57 \\
\hline DIC & 11.12 & 9.89 & 11.02 & 11.61 & 9.85 & 11.84 & 11.35 & 11.76 & 11.05 \\
\hline $\mathrm{FL}$ & 14.75 & 21.32 & 11.86 & 21.00 & 24.63 & 11.26 & 19.87 & 10.11 & 16.85 \\
\hline FP & 64.01 & 62.76 & 61.49 & 57.84 & 73.35 & 65.96 & 65.57 & 68.47 & 64.93 \\
\hline SS & 7.42 & 7.64 & 7.76 & 7.51 & 7.57 & 8.03 & 7.19 & 12.10 & 8.15 \\
\hline AT & 0.31 & 0.29 & 0.29 & 0.31 & 0.34 & 0.35 & 0.30 & 0.49 & 0.33 \\
\hline $\mathrm{pH}$ & 6.13 & 6.05 & 6.18 & 6.11 & 6.06 & 6.12 & 6.31 & 6.15 & $\begin{array}{c}6.14 \\
\text { Total }^{*}\end{array}$ \\
\hline $\mathrm{FF}$ & 6 & 8 & 5 & 6 & 5 & 2 & 3 & 3 & 9 \\
\hline BS & 3 & 3 & 3 & 3 & 2 & 1 & 1 & 2 & 3 \\
\hline AS & 3 & 2 & 3 & 3 & 1 & 1 & 2 & 2 & 3 \\
\hline PB & 2 & 2 & 1 & 1 & 1 & 1 & 1 & 1 & 2 \\
\hline DB & 3 & 2 & 2 & 3 & 3 & 2 & 2 & 2 & 3 \\
\hline ST & 2 & 2 & 2 & 2 & 2 & 2 & 2 & 2 & 2 \\
\hline PW & 1 & 1 & 1 & 2 & 2 & 2 & 2 & 2 & 2 \\
\hline
\end{tabular}

Values in parentheses are the number of accessions per group. AFW: average fruit weight (g); ST: shell thickness (cm); PT: pulp thickness $(\mathrm{cm})$; DIC: diameter of the internal cavity $(\mathrm{cm})$; FL: fruit length $(\mathrm{cm})$; FP: firmness of the pulp (N); SS: soluble solids (\%); AT: titratable acidity; $\mathrm{pH}$ : hydrogen potential. FF: fruit shape; SB: shape of the fruit base; AS: apical shape of the fruit; PB: presence of buds; DB: distance between sections; ST: surface texture; PW: presence of warts on the fruit. *Total types observed in the entire access population.

Concerning qualitative characters, the greatest variation occurred, as expected, in the shape of the fruit (Figure 4, Table 3). Group II was more variable with eight types of fruit shapes in a total of nine types observed in the evaluated germplasm. Six types of fruits were observed in groups I e IV. Variation was observed between the groups for the basal and apical formats, with groups I, III, and IV consisting of three formats for both descriptors.

All accessions have fruit with buds, but access AB-44 in the first group; and the access AB-26, second, have fruits without buds (Figure 4). There are differences between groups for the distance of the segments, with greater variability in groups I, IV, and V that presented the three possible distances. In all groups, the two types of texture were observed, with a predominance of accessions with smooth fruits in groups I, II, III, and IV, and with rough fruits, in groups IV and VIII. There was variability for the presence of warts on the fruit. The accessions of groups I, II, and III did not show warts on the fruits. Seven accessions (13.46\%) distributed in groups IV, V, VI, and VII, segregated for the presence of warts in the fruits, indicating the predominance of fruits without warts in the evaluated germplasm.

The information demonstrates that there is variability in the sample studied, and the need to increase the existing variability in the collection does not preclude the use of these accesses in pre-breeding and breeding programs.

The grouping of accessions considering both the quantitative and qualitative descriptors provided greater discrimination and distribution of accessions in the eight groups formed. As expected, there is little variation between groups for quantitative descriptors, with exceptions for fruit firmness and length. On the 
other hand, there is greater variation between and within groups for qualitative characters, especially the shape of the fruit. Even promoting the selection of accessions for commercial purposes, many farmers practice the random exchange of seeds (Ferreira 2008), allowing variability between and within the local germplasm. This fact can be observed in some accessions that have different types of fruits, different textures, presence of buds, and distance from buds.

The information generated in evaluations and characterizations is useful in two ways. In the first, from the curator's point of view, they provide subsidies for making decisions about the elimination of similar samples and the need to carry out new expeditions (Dantas et al. 2015). In the present work, it is evident that new collections of accessions are needed in Rio Grande do Norte to expand the genetic variability in the UFERSA collection, especially, mainly for quantitative characters. The results of the present study reinforce the comments of Lima et al. (2016). For these authors, the national germplasm banks have many accessions from the northeast of Brazil, collected mainly in the states of Bahia, Maranhão, and Pernambuco, but there is little material from other states, including the state of Rio Grande do Norte, even though it has great variability and one of the great domestic producers (Lima et al. 2016).

The other relevant aspect of the work concerns genetic improvement. The knowledge of germplasm arising from activities carried out in germplasm banks is useful for obtaining new cultivars. In this sense, although the variation observed in the accessions has been reduced when compared to other works consulted, this information is useful for future works of genetic improvement. A prominent example is the access AB-22 which was not grouped and has different types of fruits of smaller, larger size, soluble solids, and titratable acidity. Other accessions have promising characteristics for some characters relevant to the weight of the fruit, firmness of the pulp, and thickness of the pulp.

\section{Conclusions}

There is variability in the collection for the studied characteristics, justifying its conservation. It is necessary to implement actions that contribute to increasing the existing variability in the collection of Cucurbita moschata at UFERSA.

Authors' Contributions: PAULA RIBEIRO, R.M.: acquisition of data, analysis and interpretation of data, drafting the article; PEREIRA, C.C.A.: acquisition of data, analysis and interpretation of data; LINS, H.A.: acquisition of data, critical review of important intellectual content; BARBOSA, M.: acquisition of data; CARVALHO, I.D.E.: acquisition of data; NUNES, G.H.S: acquisition of data; SILVEIRA, L.M.: acquisition of data; BARROS JÚNIOR, A.P.: conception and design, analysis and interpretation of data, drafting the article. All authors have read and approved the final version of the manuscript.

Conflicts of Interest: The authors declare no conflicts of interest.

Ethics Approval: Not applicable.

Acknowledgments: The authors would like to thank the funding for the realization of this study provided by the Brazilian agencies CAPES (Coordenação de Aperfeiçoamento de Pessoal de Nível Superior - Brasil), Finance Code 001, and CNPq (Conselho Nacional de Desenvolvimento Científico e Tecnológico - Brasil).

\section{References}

ALVARES, C.A., et al. Köppen's climate classification map for Brazil. Meteorologische Zeitschrift. 2013, 22(6), 711-728. http://dx.doi.org/10.1127/0941-2948/2013/0507.

AMARIZ, A. Quality, bioactive compound, and antioxidant activity of access of fruits of pumpkin (Cucurbita moschata) from Active Germoplasm Bank of Cucurbits of Embrapa Tropical Semi-Arid. Mossoró, RN: Universidade Federal Rural do Semi-Árido, 2011.

BALKAYA, A., ÖZBAKIR, M. and KURTAR, E.S. The phenotypic diversity and fruit characterization of winter squash (Cucurbita maxima) populations from the Black Sea Region of turkey. African Journal of Biotechnology. 2010, 9(2), $152-162$.

BLANK, A.F., et al. Parâmetros genotípicos, fenotípicos e ambientais para caracteres morfológicos e agronômicos em abóbora. Horticultura Brasileira. 2013, 31(1), 106-111. https://doi.org/10.1590/S0102-05362013000100017

BORGES, R.M., et al. Phenotypic variability among pumpkin accessions in the Brazilian semiarid. Horticultura Brasileira. 2011, 29(4), 461-464. http://dx.doi.org/10.1590/S0102-05362011000400003 
BORGES, V.P., et al. Energy balance and evapotranspiration of melon grown with plastic mulch in the Brazilian semiarid region. Scientia Agricola. 2015, 72(5), 385-392. http://dx.doi.org/10.1590/0103-9016-2014-0136

BORGES, R.M.E., LIMA, M.A.C. and MELO, N.F. Correlations between fruit yield and sensory and nutritional quality of pumpkin (Cucurbita moschata Duch.). Australian Journal of Crop Science. 2019, 13(10), 1676-1682.

http://dx.doi.org/10.21475/ajcs.19.13.10.p1914

BRASIL. DHE Abóboras (Cucurbita spp.). 2004. Available from: http://www.agricultura.gov.br/vegetal/registrosautorizacoes/protecaocultivares/formularios-protecao-cultivares

BURLE, M.L. and OLIVEIRA, M.S.P. Manual de curadores de germoplasma - vegetal: caracterização morfológica. Brasília, DF: EMBRAPA Recursos Genéticos e Biotecnologia, 2010.

COSTA, F.R., et al. Marcadores RAPD e caracteres morfoagronômicos na determinação da diversidadegenética entre acessos de pimentas e pimentos. Ciência Rural. 2009, 39(3), 696-704. http://dx.doi.org/10.1590/S0103-84782008005000099

CRUZ, C.D., FERREIRA, F.M. and PESSONI, L.A. Biometria aplicada ao estudo da diversidade genética. 1st ed. Visconde do Rio Branco, MG: Suprema, 2011.

DANTAS, A.C.A., et al. Diversity of Melon Accessions from Northeastern Brazil and Their Relationships with Germplasms of Diverse Origins. Journal American. Society Horticulture Scince. 2015, 10(6), 505-517.

http://dx.doi.org/10.21273/JASHS.140.5.504

ESQUINAS-ALCAZAR, J.T. and GULICK, P.J. Genetic resources of cucurbitaceae. Rome: IBPGR, 1983.

FERREIRA, M.A.J.F. 2008. Abóboras e morangas. In: BARBIERI, R.L. and STUMPF, E.R.T. (Eds.). Origem e evolução de plantas cultivadas. 1st ed. Brasília-DF: EMBRAPA Informação Tecnológica, pp. 59-88.

FERREIRA, M.G., et al. Parâmetros genéticos, dissimilaridade e desempenho per se em acessos de abóbora. Horticultura Brasileira. 2016, 34(4), 537-546. http://dx.doi.org/10.1590/s0102-053620160413

GLIEMMO, M.F., et al. Color stability of pumpkin (Cucurbita moschata. Duchesne ex Poiret) puree during storage at room temperature: effect of $\mathrm{pH}$. potassium sorbate. ascorbic acid and packaging material. Food Science and Technology. 2009, 42(1), 196-201. http://dx.doi.org/10.1016/j.Iwt.2008.05.011

GUINÉ, R.P.F., HENRIQUES, F. and BARROCA, M.J. Mass Transfer Coefficients for the Drying of Pumpkin (Cucurbita moschata) and Dried Product Quality. Food Bioprocess Technology. 2012, 5(1), 176-183. http://dx.doi.org/10.1007/s11947-009-0275-y

LIMA, G.K.L., QUEIRÓZ, M.A. and SILVEIRA, L.M. Rescue of Cucurbita spp. germplasm in Rio Grande do Norte. Revista Caatinga. 2016, 29(1), 257-262. http://dx.doi.org/10.1590/1983-21252016v29n130rc

OLIVEIRA, R.L., et al. Genetic divergence among pumpkin landraces. Semina: Ciências Agrárias. 2016, 37(2), 547-556. http://dx.doi.org/10.5433/1679-0359.2016v37n2p547

PAULA RIBEIRO, R.M., et al. Indirect selection for content of carotenoid in pumpkin accessions. Revista de la Facultad de Ciencias Agrarias UNCuy. 2020, 52(2), 12-21.

R CORE TEAM. A language and environment for statistical computing. $R$ Foundation for Statistical Computing, Vienna, $R$ Foundation for Statistical Computing. 2019. Available from: http://www.R-project.org/

RAMOS, S.R.R., et al. Divergência genética em germoplasma de abóbora procedente de diferentes áreas do Nordeste. Horticultura Brasileira. 2000, 18(3), 195-199. http://dx.doi.org/10.1590/S0102-05362000000300011

RAMOS, S.R.R., et al. Aspectos técnicos do cultivo da abóbora na região Nordeste do Brasil. Aracaju, SE: EMBRAPA Tabuleiros Costeiros, 2010.

RESENDE, M.D.V. SELEGEN-REM/BLUP: sistema estatístico e seleção genética computadorizada via modelos lineares mistos. Colombo: EMBRAPA Florestas, 2007.

RÊGO, L.G.S., et al. Pedogenesis and soil classification of an experimental farm in Mossoró, State of Rio Grande do Norte, Brazil. Revista Caatinga. 2016, 29(4), 1036-1042. http://dx.doi.org/10.1590/1983-21252016v29n430rc

SANTOS, J.O., et al. Estabilidade fenotípica em abóbora. Horticultura Brasileira. 2015, 33(4), 498-503.

http://dx.doi.org/10.1590/S0102-053620150000400015

SCOTT-KNOTT, A.J. and KNOTT, M. Cluster analysis method for grouping means in the analysis of variance. Biometrics. 1974, 30(1), 507-512.

SILVA, J.M., et al. Implicações da interação genótipos x ambientes sobre ganhos com a seleção em meloeiro. Ciência Rural. 2011, 41(1), 51-56. http://dx.doi.org/10.1590/S0103-84782011000100009 
SILVA, A.R., MALAFAIA, G. and MENEZES, I.P.P. Biotools: an $r$ function to predict spatial gene diversity via an individual-based approach. Genetics and Molecular Research. 2017, 16(2), 1-6. http://dx.doi.org/10.4238/gmr16029655

SINGH, D. The relative importance of characters affecting genetic divergence. Indian Journal of Genetic and Plant Breeding. 1981, 41(2), 237-245.

SINGH, A., et al. Genetics, Physiological Mechanisms and Breeding of Flood-Tolerant Rice (Oryza sativa L.). Plant and Cell Physiology. 2017, 58(2), 185-197. https://doi.org/10.1093/pcp/pcw206

VERONEZI, C.M. and JORGE, N. Aproveitamento de sementes de abóbora (Cucurbita sp.) como fonte alimentar. Revista Brasileira de Produtos Agroindustriais. 2012, 14(1),113-124, 2012. http://dx.doi.org/10.15871/1517-8595/rbpa.v14n1p113-124

Received: 16 April 2020 | Accepted: 26 October 2020 | Published: 16 February 2022

This is an Open Access article distributed under the terms of the Creative Commons Attribution License, which permits unrestricted use, distribution, and reproduction in any medium, provided the original work is properly cited. 